Special issue of the 3rd International Conference on Computational and Experimental Science and Engineering (ICCESEN 2016)

\title{
Effect of Boriding on the Fatigue Resistance of C20 Carbon Steel
}

\author{
A. Barkat*, A.D. Hammou and O. Allaoui \\ Laboratoire de Génie des Procédés, Université Amar Telidji, Laghouat 03000, Algeria
}

\begin{abstract}
Boriding is a thermochemical surface treatment used to improve corrosion and wear resistance of hardened steels. In this work, we study the effect of boriding treatment in solid medium on the cyclic fatigue resistance of C20 carbon steel. Specimens of untreated and borided C20 steel in a solid medium consisting of $5 \%$ B ${ }_{4}$, $5 \%$ $\mathrm{NaBF}_{4}$ and $90 \% \mathrm{SiC}$ were subjected to rotating-bend fatigue device. The results showed that the improvement in fatigue resistance carried by the boriding treatment on C20 steel is low. This was explained by the presence of $\mathrm{FeB}$ boride in addition to $\mathrm{Fe}_{2} \mathrm{~B}$ boride, which leads to surface cracking.
\end{abstract}

DOI: 10.12693/APhysPolA.132.813

PACS/topics: C20 steel, boriding, cyclic fatigue

\section{Introduction}

The fatigue life of materials and structures is very sensitive to their surface finish. In some cases, improvement of the fatigue resistance of materials is achieved through the improvement of their surface properties. The compressive residual stresses induced by surface treatment can improve fatigue strength of the material [1,2].

Boriding is a thermochemical surface treatment that can be applied to a wide range of materials (ferrous metals, non ferrous metals, cermets, etc.). It consists in introducing by diffusion of boron atoms through the surface of the substrate. The so introduced boron atoms react with the base material to form borides. Boriding treatment allows obtaining surface hardness much higher than those obtained by other conventional treatments like hardening, nitriding or carbonitriding. Boriding thermochemical surface treatments can be achieved by various methods: in a solid medium in powders $[3,4]$ or with pastes [5], in a liquid medium of fused salts with or without electrolysis [6], or in a gaseous medium [7]. The main advantage of the boriding treatment applied to steel is that it allows combining a high surface hardness with a low coefficient of friction, which promotes a good wear resistance. Many studies have been devoted to the beneficial effect of boriding on the wear and corrosion resistance of steels $[8,9]$, but the effect on the cyclic behavior and fatigue remains unknown in general.

In this work, we study the effect of boriding treatment in solid medium on the cyclic fatigue resistance of C20 carbon steel. Specimens of untreated and borided $\mathrm{C} 20$ steel in a solid medium consisting of $5 \% \mathrm{~B}_{4} \mathrm{C}, 5 \% \mathrm{NaBF}_{4}$, and $90 \% \mathrm{SiC}$ were subjected to rotating-bend fatigue device.

\section{Experimental techniques}

*corresponding author; e-mail: ab.barkat@lagh-univ.dz
C20 steel specimens with dimensions as specified in Fig. 1 were used for fatigue testing in rotating bending machine. The chemical composition of the steel C20 is given in Table I.

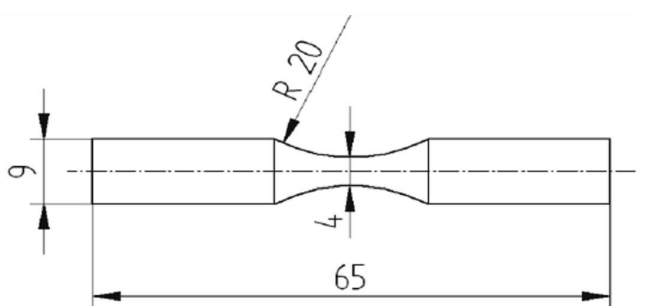

Fig. 1. Rotating-bend fatigue test samples.

TABLE I

Chemical composition [wt.\%] of the C20 steel.

\begin{tabular}{c|c|c|c|c|c|c|c|c}
\hline \hline $\mathrm{C}$ & $\mathrm{Mn}$ & $\mathrm{Si}$ & $\mathrm{P}$ & $\mathrm{S}$ & $\mathrm{Cu}$ & $\mathrm{Cr}$ & $\mathrm{Ni}$ & $\mathrm{Fe}$ \\
\hline 0.192 & 0.68 & 0.34 & 0.027 & 0.023 & 0.18 & 0.19 & 0.26 & bal.
\end{tabular}

Before boriding treatment, all samples have undergone a surface preparation with silicon carbide paper up to grade 1000 to facilitate the boron diffusion through the surface.

Boriding treatment was carried out in a powder consisting of $90 \% \mathrm{SiC}$ as a diluent, $5 \% \mathrm{~B}_{4} \mathrm{C}$ as boron source and $5 \% \mathrm{NaBF}_{4}$ as activator. According to previous work, a treatment of $4 \mathrm{~h}$ at $900^{\circ} \mathrm{C}$ was done to obtain an average borided layer thick of about $150 \mu \mathrm{m}$. After the boriding treatment, all samples were allowed to cool in air.

In addition to observation in optical and scanning electron microscopy, the phase identification of the treated samples was made by X-ray diffraction using Panalytical X'Pert Pro X-ray Diffractometer.

Hardness values of the samples were measured by using a Mitutoyo MVK-H2 microhardness tester. The changing of the hardness values from the surface to the substrate 
was determined on the Vickers indentation by applying a load of 50 gf for borided layer and 100 gf for underlying zone and substrate.

The fatigue tests were carried out with a rotational bending machine. Different loads were applied to borided and untreated specimens under the same conditions until failure. For each load, we considered three pieces and we took the average value as the average stress. S-N fatigue diagrams of borided and untreated specimens were plotted and compared.

\section{Results and discussions 3.1. Boriding of C20 steel}

Boriding treatment carried out at $900{ }^{\circ} \mathrm{C}$ for $4 \mathrm{~h}$ leads to borided layer of about $150 \mu \mathrm{m}$ depth. The microstructure of borided layer, obtained on $\mathrm{C} 20$ as a consequence of boriding treatment at $900^{\circ} \mathrm{C}$ for $4 \mathrm{~h}$, consisted of two phases: $\mathrm{FeB}$ at the surface and $\mathrm{Fe}_{2} \mathrm{~B}$ below, with predominance of $\mathrm{Fe}_{2} \mathrm{~B}$ boride.

Figure $2 \mathrm{a}$ and $\mathrm{b}$ shows the microstructure of $\mathrm{C} 20$ steel before and after boriding treatment.

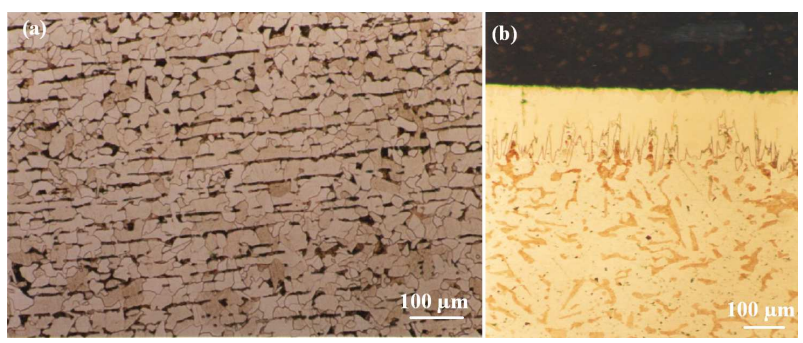

Fig. 2. Microstructure of C20 steel: (a) before boriding treatment, and (b) after boriding treatment at $900{ }^{\circ} \mathrm{C}$ for $4 \mathrm{~h}$.

The borided layers obtained on the surface of C20 steel have an acicular shape morphology oriented perpendicularly to the treated surface.

The identification of the boride layers formed on the surface of C20 steel by X-ray diffraction and the observation by optical and scanning electron microscopy revealed that these boride layers consist essentially of $\mathrm{Fe}_{2} \mathrm{~B}$ boride inwards and a low proportion of $\mathrm{FeB}$ boride to the outside.

Based on the observations made on the sections of the borided specimens, we recorded three different zones:

1. The borided layer,

2. An underlying zone, and

3. The substrate.

\subsection{Microhardness}

To evaluate the effect of the boriding treatment on the surface of C20 steel, microhardness measurements were carried out on the three different zones. The microhardness values corresponding to the different zones are summarized in Table II
TABLE II

Microhardness values of different zones of borided C20 steel.

\begin{tabular}{c|c}
\hline \hline Zone & Microhardness [HV] \\
\hline borided layer & 1840 \\
underlying & 670 \\
substrate & 180
\end{tabular}

The hardness values obtained from the surface towards the core of the substrate represent a hardness gradient which can be very advantageous during rotational bending tests [10].

\subsection{Fatigue tests}

Results of fatigues tests on borided and untreated specimens are shown in Fig. 3. S-N curves representing borided samples have been compared with $\mathrm{S}-\mathrm{N}$ curves of untreated samples. This comparison has pointed out that fatigue strength of borided specimens is slightly better than of untreated ones.

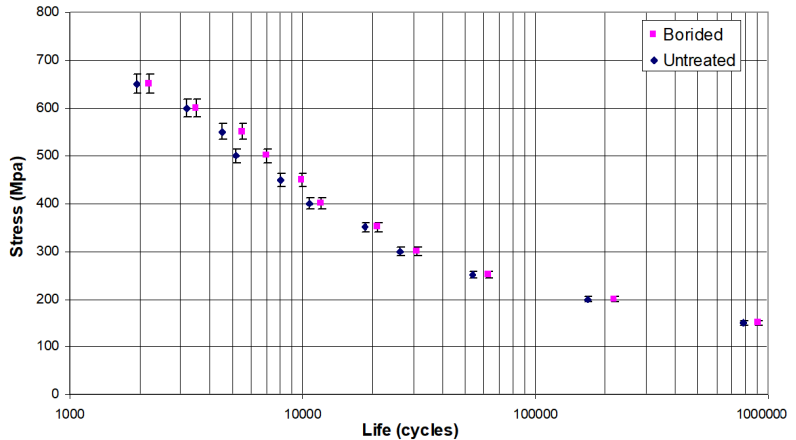

Fig. 3. S-N curve for borided and untreated C20 steel.

Contrary to the results obtained by Bouaziz et al. [10] where they found that the boriding of an XC38 steel in a molten salt consisting of borax and $\mathrm{SiC}$ reduces its fatigue strength by 20 to $25 \%$, we have found that the boriding treatment performed on C20 steel improves the fatigue strength of this steel by about $20 \%$.

The results are shown in Fig. 3. Let us indicate that the improvement in fatigue resistance carried by the boriding treatment on $\mathrm{C} 20$ steel is low. This was explained by the presence of the boride $\mathrm{FeB}$ in addition to the $\mathrm{Fe}_{2} \mathrm{~B}$ boride, which leads to surface cracking.

\section{Conclusions}

The effect of boriding treatment on C20 steel has been investigated in this work. Boriding treatment was carried out in powder mixture consisting of: $5 \% \mathrm{~B}_{4} \mathrm{C}$ as boron source, $5 \% \mathrm{NaBF}_{4}$ as activator and $90 \% \mathrm{SiC}$ as diluent for $4 \mathrm{~h}$ at $900^{\circ} \mathrm{C}$. Optical microscope, SEM, XRD and microhardness characterization of borided layers was done. Cyclic fatigue tests were realized and $\mathrm{S}-\mathrm{N}$ curves have been plotted.

Towards the end of this investigation, we can point the following conclusions: 
1. The boriding treatment at $900{ }^{\circ} \mathrm{C}$ for $4 \mathrm{~h}$ allowed to obtain a borided layer of about $150 \mu \mathrm{m}$ with acicular shape on the surface of the steel C20. It should be noted that $\mathrm{Fe}_{2} \mathrm{~B}$ boride was predominant in the borided layer.

2. Microhardness measurements from the surface to the substrate core showed a hardness gradient from the surface with a maximum value of $1840 \mathrm{HV}$ and a minimum value of $180 \mathrm{HV}$ at the core of the substrate.

3. According to the S-N curve, the lifetimes of borided samples are relatively improved compared to the untreated samples. For all applied loads, the fatigue life of borided samples was increased by about 15-20\% compared to untreated samples.

\section{References}

[1] X. Yang, X. Ling, J. Zhou, Int. J. Fatigue 61, 28 (2013).
[2] A. Günen, Acta Phys. Pol. A 130, 217 (2016).

[3] N. Uzunov, R. Ivanov, Appl. Surf. Sci. 225, 72 (2004).

[4] N. Ucar, N. Turku, A.F. Ozdemir, A. Calik, Acta Phys. Pol. A 130, 492 (2016).

[5] I. Campos, R. Torres, O. Bautista, G. Ramírez, L. Zuniga, Appl. Surf. Sci. 252, 2396 (2006).

[6] K. Matiašovský, M. Chrenková-Paučírová, P. Fellner, M. Makyta, Surf. Coat. Technol. 35, 133 (1988).

[7] M. Kulka, N. Makuch, A. Pertek, A. Piasecki, Mater. Character. 72, 59 (2012).

[8] M. Enver Atık, U. Yunker, C. Merıç, Tribol. Int. 36, 155 (2003).

[9] E. Dokumaci, I. Özkan, B. Önay, Surf. Coat. Technol. 232, 22 (2013).

[10] S.A. Bouaziz, N. Boudaoud, A. Zanoun, Mater. Techn. 97, 253 (2009). 